\title{
PERSPECTIVE
}

\section{Adverse effects of topical antiglaucomatous medications on the conjunctiva}

\author{
David Broadway, Ian Grierson, Roger Hitchings
}

With selected patients glaucoma filtration surgery is highly successful. However, there is growing evidence that chronic topical medical therapy has a deleterious effect on surgical outcome. It has been suspected that topical drugs exert an adverse effect on the conjunctiva which results in altered postoperative wound healing. In this review the effect of previous topical antiglaucoma medication on the conjunctiva and the outcome of subsequent glaucoma filtration surgery are discussed.

\section{The effect of previous topical therapy on the results of} glaucoma filtration surgery

In a study aimed at identifying potential risk factors for failure of pressure control following glaucoma triple procedures (trabeculectomy, cataract extraction and intraocular lens implantation), the only significant adverse factor identified was cumulative years of preoperative topical therapy (number of medications $\times$ the treatment duration for each). ${ }^{1}$ The hazard ratio for this factor was $1 \cdot 1$ indicating that the risk of failure doubled after 8 years of cumulative therapy. The number of preoperative medications used was not isolated as a significant risk factor and the data were insufficient to identify any specific type of medication as the major risk factor.

In a similar study, ${ }^{2}$ previous treatment with multiple topical agents was reported to be associated with a lower trabeculectomy success rate in comparison with a group of patients undergoing primary trabeculectomy (Fig 1). The largest single influence on the outcome of trabeculectomy alone was the number of preoperative antiglaucoma medications used (hazard ratio $=5$ ). This effect persisted despite

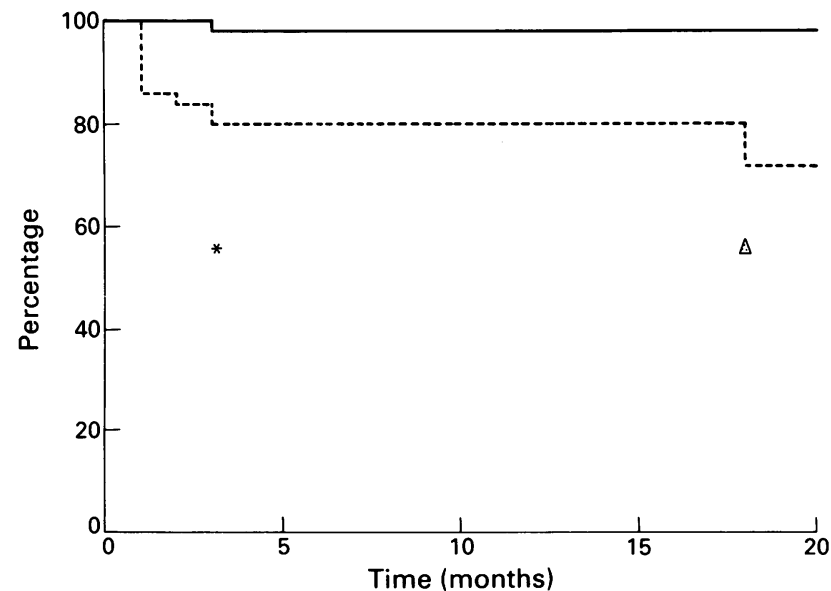

Figure 1 Percentage of successfully functioning trabeculectomies: primary surgery group (-) compared with multiple treatment group (----). There were significantly more failures in the multiple treatment group by 3 months $(p<0.005)(\star)$, with additional failures by 18 months $(p<0.001)(\triangle)$. (From Lavin $\mathrm{et}^{2} \mathrm{al}^{2}$ with permission of the American Medical Association.) controlling for factors that may have been confounders for the effect of medication number, in particular the presenting intraocular pressure (IOP). Since it was probable that the higher the IOP, the greater the number of treatments used, a higher order interaction was suspected. The duration of topical treatment was also significant, but with a hazard ratio just below 1, a longer duration appeared to have a borderline protective effect. It was thus proposed that large numbers of medications used during a relatively short period may have a greater adverse effect than the same amount of treatment over a long period. Previous exposure to sympathomimetics was identified as a significant adverse factor and the patients whose trabeculectomies failed had used more adrenalinebased preparations than those whose trabeculectomies were successful ( $55 \%$ vs $26 \%)$. In contrast, previous exposure to timolol had no significant effect on the outcome of surgery. Previous exposure to pilocarpine was not identified as a significant adverse factor, but this may have been due to the fact that only $2 \%$ of the treated patients in this study had not received pilocarpine and its use was thus a very poor determinant of risk of failure.

Previous topical therapy has also been identified as an adverse factor for the outcome of trabeculectomy performed in children with congenital glaucoma. ${ }^{3}$ With failure defined as an IOP $>21 \mathrm{~mm} \mathrm{Hg}$ the adjusted risk ratio was $5 \cdot 6$, and when defined as the requirement of additional surgical or medical therapy it was $7 \cdot 2$. Analysis by multiple regression also showed that the effect of previous topical therapy was detrimental, reducing the quality of IOP control at 3,6 , and 12 months. The effects of treatment type, amount, or duration were not analysed.

Topical therapy with sympathomimetics has also been reported to increase the risk of failure secondary to the development of Tenon's capsule cysts with a relative risk of $1.9 .{ }^{+}$Neither miotics nor $\beta$ blockers had a significant effect on the development of cysts but the effect of duration or amount of topical treatment was not addressed in this study and it is possible that the effect of sympathomimetics reflected these factors rather than one of treatment type.

\section{Table 1 Mechanism by which the conjunctiva can react to drugs}

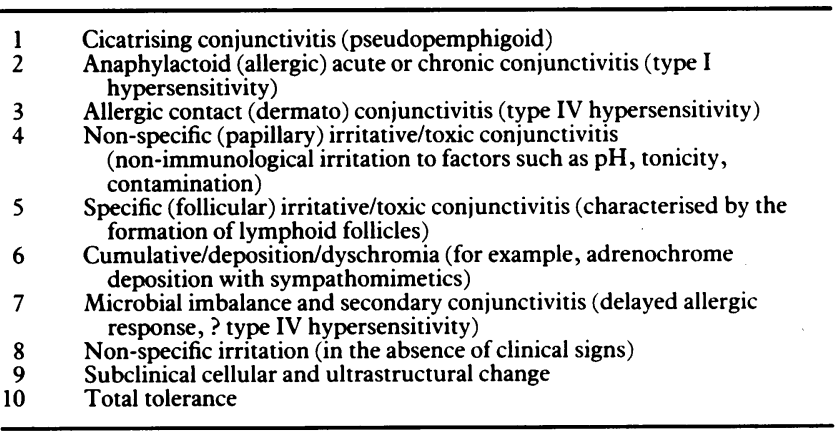



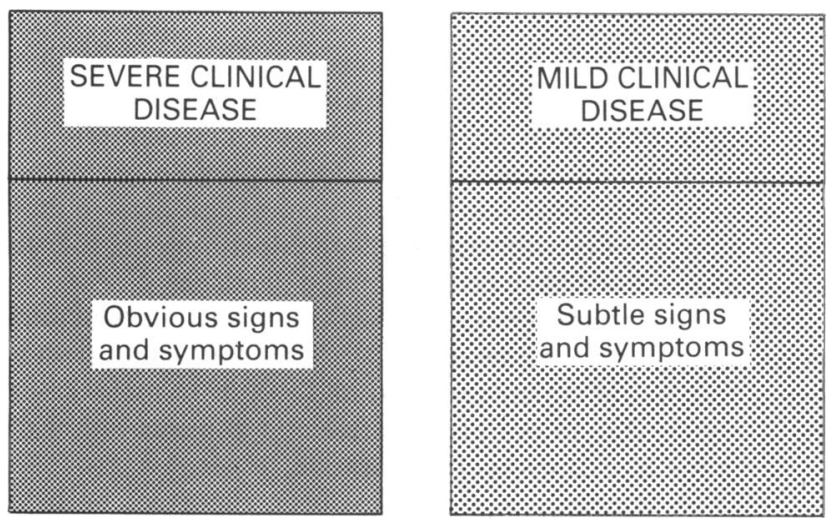

Figure 2 The spectrum of conjunctival reaction to topical medication.

In conclusion it appears that long term therapy with topical antiglaucoma medications has an adverse effect on the outcome of filtration surgery, both in terms of success and the occurrence of complications. The specific factors of importance remain unknown, but it would appear that cumulative duration of preoperative therapy and, in particular, use of sympathomimetics are risk factors of particular significance. Despite the comprehensive statistical analysis used in these studies their retrospective nature means that the results have to be regarded as tentative. Unfortunately no prospective study has yet been published.

\section{Effect of topical antiglaucoma medications on the conjunctiva}

The reasons for the higher failure rate of glaucoma filtering surgery associated with previous topical therapy are not clear and several factors may be involved. It is likely that topical preparations are able to affect all parts of the eye including the aqueous and the trabecular meshwork. Since postoperative subconjunctival fibrosis is the commonest cause of trabeculectomy failure, the effect of topical medications on the conjunctiva and subconjunctival tissues is of particular interest. Sympathomimetics, in particular, are frequently associated with local effects including subjective irritation,

\section{Table 2 Clinical features of pseudopemphigoid}

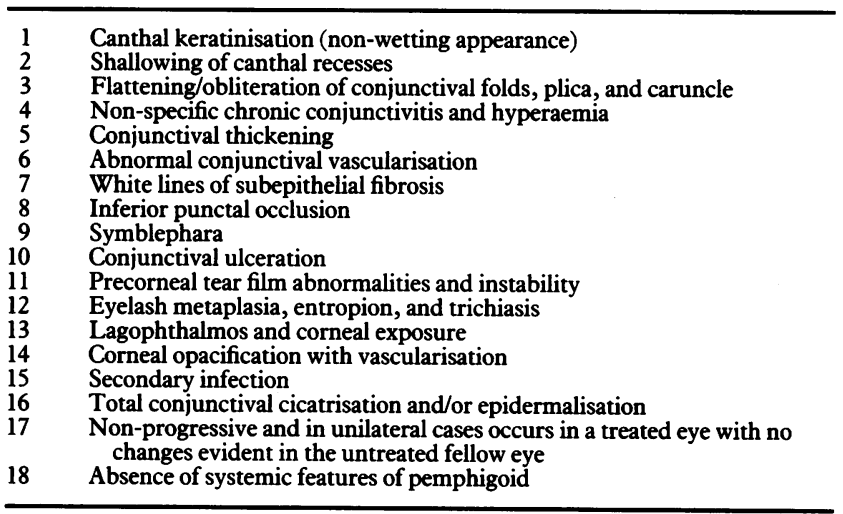

Table 3 Histopathological, ultrastructural, and immunological features of pseudopemphigoid

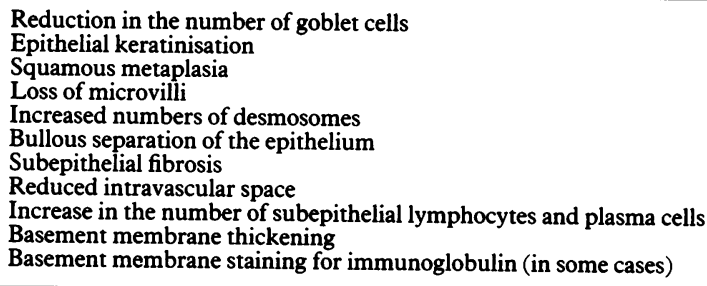

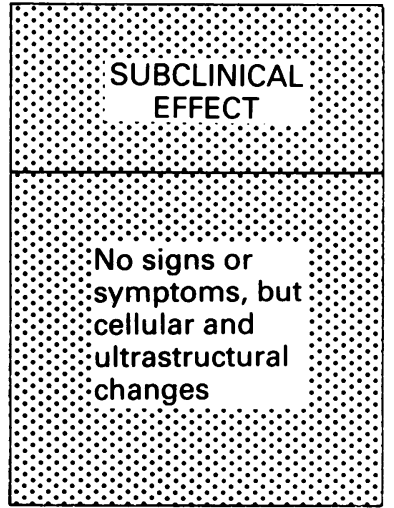

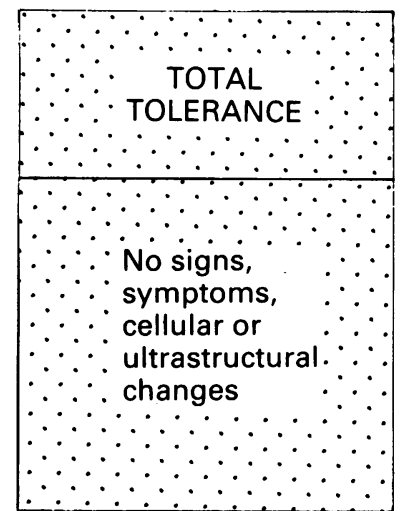

epithelial adrenochrome deposition, reactive hyperaemia, blepharoconjunctivitis, and corneal oedema, ${ }^{5-7}$ but there is growing evidence that other medications also affect the conjunctiva.

Theodore $^{8}$ and Wilson ${ }^{910}$ have reviewed the adverse external ocular effects of a number of topical drugs, including antiglaucomatous medication. It is clear that the conjunctiva is able to react in a number of ways in response to topical therapy (Table 1). It is probable that the development of pseudopemphigoid (drug-induced ocular cicatrisation) lies at the severe end of a spectrum of reactions, the other end of which is total tolerance (Fig 2). On a clinical basis this concept is logical, for a full range of tolerance is seen in ophthalmic practice.

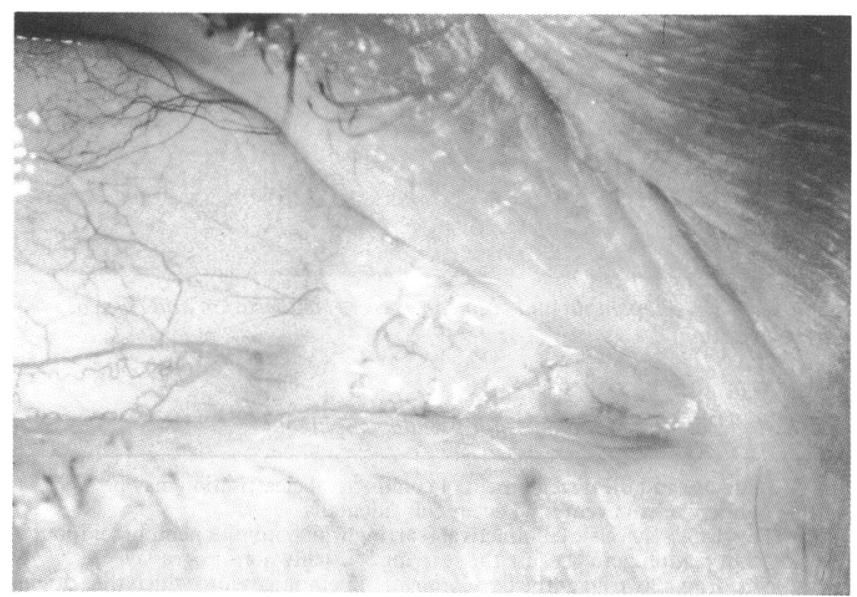

Figure 3 Pseudopemphigoid. Note the canthal disturbance and non-wetting appearance.

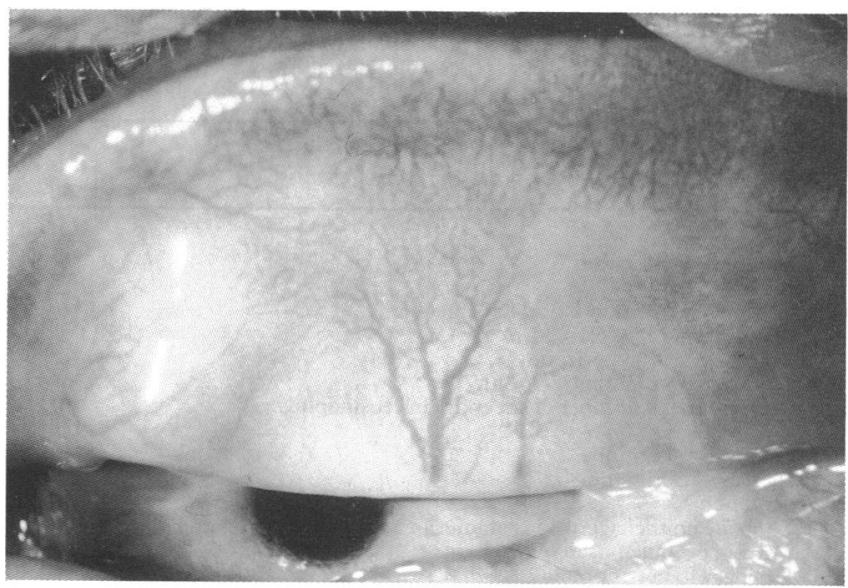

Figure 4 Pseudopemphigoid. Note the subtarsal subepithelial fibrosis and the abnormal vascular pattern. 
SEVERE CLINICAL EFFECTS

The number of reported cases of pseudopemphigoid related to the use of topical medications is relatively small but various topical antiglaucoma medications have been implicated in its aetiology. These include adrenaline, ${ }^{11-13}$ pilocarpine, ${ }^{13-15}$

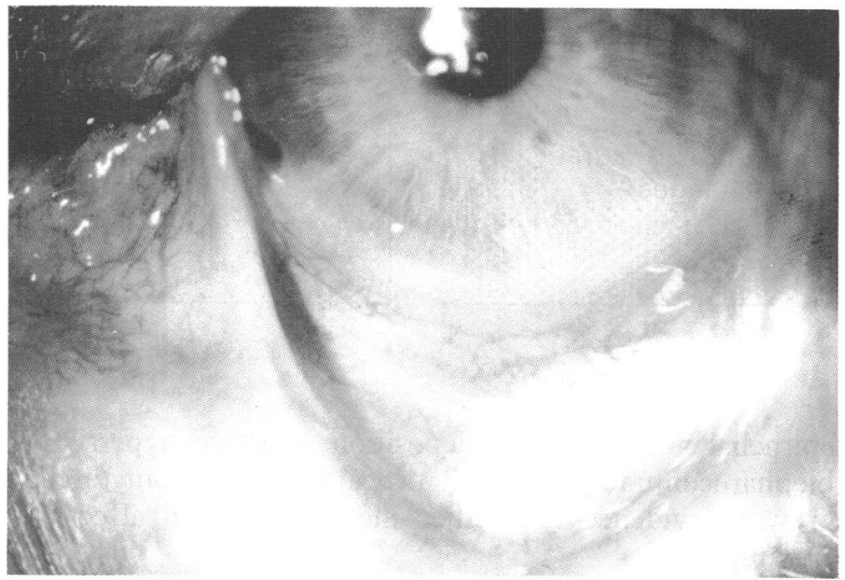

Figure 5 Pseudopemphigoid. Note the abnormal medial canthus, an inferonasal symblepharon, subepithelial fibrosis, and the thickened appearance of the conjunctiva.

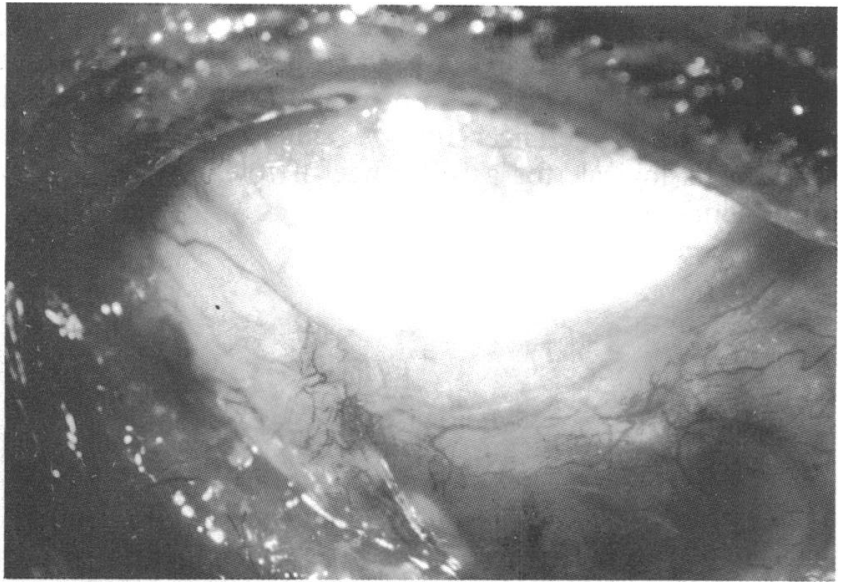

Figure 6 Pseudopemphigoid. Note the severe cicatrisation and corneal vascularisation.

\section{Table 4 Potential aetiologies for pseudopemphigoid}

\begin{tabular}{ll}
\hline 1 & $\begin{array}{c}\text { Drug use and the development of conjunctival cicatrisation may be } \\
\text { independent events and occur coincidentally }\end{array}$ \\
2 & $\begin{array}{c}\text { The drug may cause conjunctival scarring which mimics pemphigoid, but is } \\
\text { not pemphigoid because the scarring is usually non-progressive }\end{array}$ \\
3 & $\begin{array}{c}\text { The drug may trigger the development of pemphigoid, to which the patient } \\
\text { may be predisposed }\end{array}$ \\
4 & $\begin{array}{c}\text { The drug may be the cause of pemphigoid, pseudopemphigoid being } \\
\text { identical to 'true' pemphigoid }\end{array}$ \\
5 & $\begin{array}{c}\text { Pseudopemphigoid represents a spectrum of diseases ranging from a } \\
\text { self-limiting, toxic form to a progressive, immunological form }\end{array}$ \\
6 & $\begin{array}{c}\text { Pre-existing but undiagnosed pemphigoid causes scarring which may } \\
\text { obstruct collecting vessels of the outflow pathway and result in glaucoma } \\
\text { requiring topical therapy }\end{array}$ \\
\hline
\end{tabular}

Table 5 Clinical features of allergic conjunctivitis

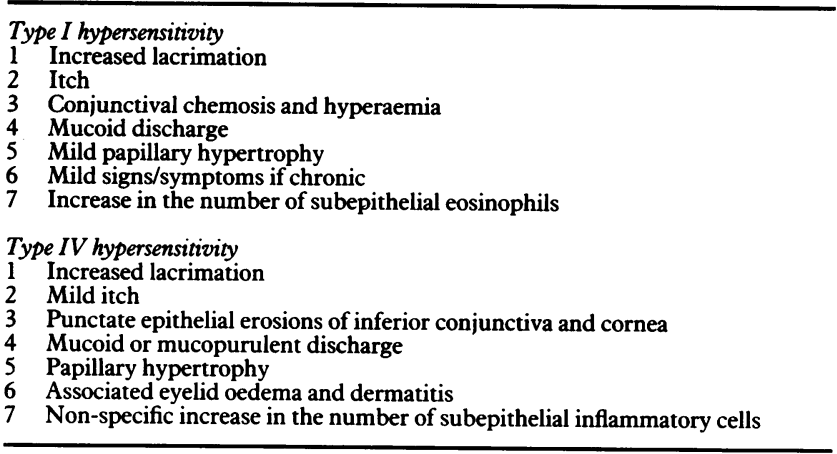

$\beta$ blockers, ${ }^{13}$ echothiophate iodide, ${ }^{1316}$ demecarium bromide, ${ }^{14}$ and various combinations of therapy..$^{13151718}$ The clinical and pathological features are summarised in Tables 2 and 3 and illustrated in Figures 3-6. The underlying aetiology of drug-induced pseudopemphigoid remains unknown with inconsistent immunological findings. However, a number of possible mechanisms explaining the role of topical medications have been proposed (Table 4). ${ }^{13} 18-20$

Allergic reactions associated with topical antiglaucoma medications have been described, ${ }^{921-24}$ the clinical and pathological features of which are listed in Table 5. In many cases the allergy is due to the preservative and administration of preservative-free drops is often curative.

Follicular conjunctivitis has also been reported, both in response to sympathomimetic (dipivefrin) ${ }^{s}$ and miotic therapy. ${ }^{95}$ Furthermore, Cvetkovic et $a l^{26}$ reported the development of conjunctival follicles after long term $(>1$ year) exposure to pilocarpine and reported that this was unrelated to the presence or absence of preservative. There is no evidence that $\beta$ blockers induce a follicular response and this provides further evidence that preservatives are not directly involved.

\section{SUBTLE CLINICAL EFFECTS}

Despite the many ways in which the conjunctiva can react to topical medications, the majority of patients are able to tolerate such therapy and clinically obvious conjunctival changes remain the exception rather than the rule. Clinical signs are not always striking, however, and subtle changes are easily missed without a rigorous examination. Wright, ${ }^{27}$ for example, reported the development of relatively subtle squamous metaplasia or epidermalisation as an adverse reaction to topical antiglaucomatous medication. The first detectable change in the cases he observed was a loss of epithelial wetting by the tear film with disturbance of the light reflex from the conjunctival surface. Increasing keratinisation created a whitish, slightly foamy appearance and in cases where this remained unnoticed a thick white mass of keratin eventually formed. Histological findings included loss of goblet cells, epithelial keratinisation, keratohyaline granule formation, subepithelial infiltration with lymphocytes and plasma cells, and, in some cases, an increase in the number of fibroblasts and degree of fibrosis. The clinical signs resolved after cessation of the therapy, but since the conjunctiva was not re-biopsied it is not known if the histological changes were completely reversed. A similar reaction has been reported after use of topical dipivefrin and metipranolol. ${ }^{28}$ In view of the pharmacological similarities between metipranolol and practolol, a systemically administered drug known to cause ocular cicatrisation, ${ }^{29}{ }^{30}$ the authors considered the $\beta$ blocker to be the cause of the conjunctival reaction.

Wright ${ }^{31}$ has shown that inferior forniceal shallowing due to subconjunctival fibrosis may be induced by sympathomimetic therapy. A recent study has further investigated this frequently subtle reaction to topical medication..$^{32}$ A significant foreshortening of the inferior fornix was found with increasing age and, after taking this into account, after at least 3 years' exposure to topical antiglaucoma medications, irrespective of type. The fact that different classes of topically administered medications were associated with conjunctival shrinkage indicated that a common pathway may result in fibrosis.

\section{SUBCLINICAL EFFECTS}

In order to determine the effect of topical antiglaucoma medications on the cellular content on the conjunctiva, Sherwood $e t a l^{33}$ quantitatively analysed biopsies obtained 


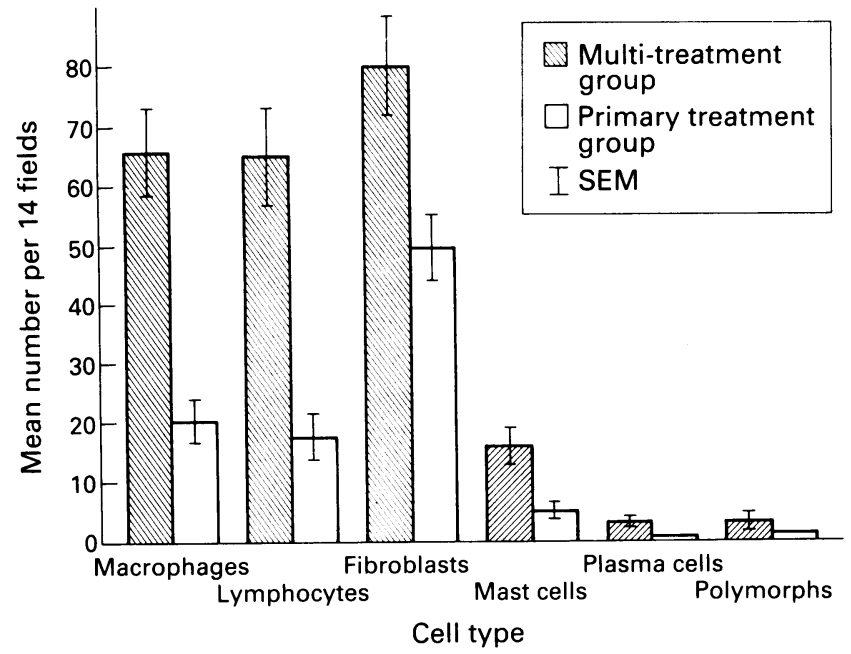

Figure 7. Bar graph comparing mean cell counts in the conjunctival substantia propria between primary and multiple treatment group patients. There is a significant increase in macrophages, lymphocytes, mast cells, and fibroblasts in the multiple treatment group. (From Sherwood et $\mathrm{al}^{33}$ with permission.)

from patients with glaucoma undergoing filtration surgery. The patients were divided into two groups. Primary trabeculectomy patients underwent trabeculectomy within a few weeks of their glaucoma diagnosis, following treatment with pilocarpine for a mean duration of only 3 weeks. Multitreatment patients underwent trabeculectomy after treatment with at least two different types of topical medication, for a minimum duration of 1 year (mean $7 \cdot 7$ years). In the epithelium, the multi-treatment conjunctiva showed a significant decrease in the number of goblet cells and increase in the number of cysts and non-epithelial cells such as lymphocytes or macrophages. A significant increase in the number of fibroblasts, macrophages, lymphocytes, and mast cells was found in both conjunctival substantia propria and Tenon's capsule (Fig 7). The authors proposed that the increased number of fibroblasts and inflammatory cells in conjunctiva exposed to topical medications might enhance the risk of bleb failure after trabeculectomy. This study is of both interest and importance but did not identify whether any specific antiglaucoma medication was responsible.

In order to identify specific drugs responsible for such changes, Smith et $\mathrm{al}^{34}$ investigated the effect of antiglaucoma medications on the conjunctiva of rabbits, divided into four groups. Timolol, pilocarpine, adrenaline, or a combination of all three drugs were placed in one eye, twice daily, for 7 months. The fellow eye received distilled water and acted as a control. Analysis of the number of inflammatory cells, fibroblasts, and goblet cells revealed no statistically significant difference in number of any cell type between the control and treatment groups. However, as the authors point out the small number of eyes in each treatment group and the high variability in cell counts between each eye limited the power of such an analysis. A number of other reasons to explain the difference between these results and those of Sherwood t al were discussed. Firstly, the mean durations of topical therapy were significantly different, 7 months rather

Table 6 Potential factors of importance in the aetiology of the adverse effect of topical medication on the conjunctiva

\footnotetext{
Type of medication

Type of preservative

Number of medications

Combination therapy

Duration of therapy
Cumulative duration of therapy

Cumulative duration of th
Frequency of application

Physical properties of preparation ( $\mathrm{pH}$, toxicity, concentration,

temperature)
}

than $7 \cdot 7$ years. Secondly, the treatment groups were not comparable. Sherwood et al did not specify the types of medication used, but each patient had used a combination of medications. In addition, pilocarpine was only administered twice daily to the rabbits, rather than the usual four times a day. Thirdly, tissue handling and cell counting techniques differed. More importantly, perhaps, is the fact that animal models are not always representative of humans. The rabbit eye is relatively large and prominent, such that loss of effective drug from the exposed eye and reduced drug exposure time may be factors of importance in comparison with humans.

Our own work ${ }^{35}$ showed that long term therapy with $\beta$ blocker alone had little effect on the cellular profile of the conjunctiva, whereas pilocarpine increased the number of macrophages in the epithelium, and fibroblasts and mast cells in the substantia propria. Pilocarpine in combination with $\beta$ blocker resulted in an increase in the number of Langerhans cells and macrophages in the epithelium, and fibroblasts and lymphocytes in the substantia propria. Triple therapy (pilocarpine in combination with $\beta$ blocker and sympathomimetic) had the greatest effect in reducing goblet cells and increasing Langerhans cells, macrophages, and lymphocytes in the epithelium, and fibroblasts, macrophages, lymphocytes, and mast cells in the substantia propria. The reaction to topical treatment is not caused solely by type of medication and a number of factors appear to be important (Table 6).

No other morphometric studies on patients treated with only one type of medication have been performed, although a few studies have looked at the effect of either single or multiple topical medications on specific features of the conjunctival surface. Surface changes themselves may have little effect on bleb formation or failure following trabeculectomy, but they may be indicative of subepithelial changes of more importance.

A number of studies have reported that application of $\beta$ blocker results in asymptomatic corneal anaesthesia and tear film changes, ${ }^{9636-11}$ but other studies ${ }^{42-4}$ report that such changes, if present, are usually clinically insignificant.

Conjunctival surface changes secondary to long term $\beta$ blocker application have, however, been identified by a number of workers..$^{36+6}$ These changes have included epithelial oedema, a reduction in goblet and secretory epithelial cells, a pronounced increase in cells with rough endoplasmic reticulum, abnormalities of the Golgi apparatus, a loss of desmosomes and tight junctions, and a reduction in the number of microvilli.

Steuhl et $a l^{16}$ proposed that intracellular changes such as vacuolisation and dilatation of the rough endoplasmic reticulum of surface epithelial cells may be attributable to the action of preservative (benzalkonium chloride). Since these changes were greatest with $\beta$ blocker medications it was proposed that the cytotoxic action of the preservative was intensified by the simultaneous application of $\beta$ blockers because of their destabilising effect on the tear film.

In contrast, Quaranta $e t a l^{47}$ reported no evidence of pathological alterations to the conjunctiva after long term (6-10 years) therapy with timolol, although only four patients were compared with four controls. A similar conclusion was reached by Hoffman ${ }^{18}$ who reported that timolol placed in rabbit eyes for 1 year or beagle eyes for 2 years had no histomorphological effect on the conjunctiva.

The effect of pilocarpine on the density of goblet cells has been investigated by Gerstenberger and Marquardt who also demonstrated a circadian rhythm in goblet cell number. ${ }^{+9}$ Long term use of pilocarpine (up to 20 years) was found to be associated with an increase in goblet cell number and it was proposed that this increase occurred secondary to maximal parasympathomimetic stimulation of the goblet cells. An 


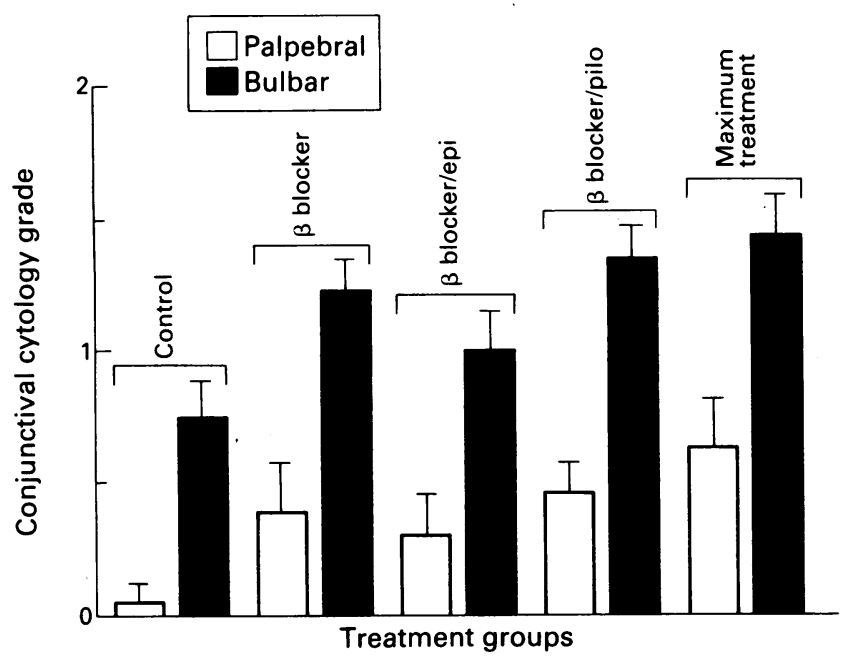

Figure 8 Graph comparing the conjunctival impression cytologic grade of both bulbar and palpebral conjunctivae in the patient groups studied. (From Brandt et $\mathrm{al}^{52}$ with permission of the American fournal of Ophthalmology.)

anatomical study, however, has shown that epithelial goblet cells are not parasympathomimetically innervated..$^{50}$ It is more probable that goblet cell activity is increased to keep pace with the increased rate of lacrimal gland secretion induced by the pilocarpine. ${ }^{\mathrm{S1}}$

The results of Gerstenberger and Marquardt ${ }^{49}$ contrast with those of others ${ }^{27} 3^{35}$ but may indicate that in the latter studies medications other than pilocarpine caused the reduction in goblet cell number.

The results of all these studies ${ }^{273449}$ contrast with the findings of Steuhl $e t a l^{46}$ who reported that pilocarpine had a minimal effect on conjunctival cell differentiation.

Brandt $e t a l^{52}$ used conjunctival impression cytology to assess the effect of topical antiglaucoma medication on the degree of epithelial metaplasia. Impression cytology specimens from patients on a stable regimen of up to three topical medications, for a minimum duration of 3 months, were compared with those from glaucoma suspects unexposed to topical medication. The control group had the lowest cumulative metaplasia score, consistent with healthy conjunctiva. The degree of metaplasia of three treatment groups ( $\beta$ blocker alone, $\beta$ blocker with pilocarpine, and $\beta$ blocker with pilocarpine and sympathomimetic) was significantly increased in comparison with the control group (Fig 8). A series of eyes treated with a combination of $\beta$ blocker and sympathomimetic had a mean grade slightly higher than the control group but this was not statistically significant. The authors proposed that the reduced effect in this group could be explained if the effect on the conjunctiva were mediated at the adrenergic receptor such that a combination of adrenergic agonist and antagonist resulted in little overall effect. Since the largest difference was seen in the comparison between control group and triple therapy group the authors suggested that the increased degree of metaplasia was associated with the number of antiglaucoma medications used. This conclusion cannot be made unequivocally with their data, and other factors such as the duration of therapy were not analysed. Since most patients receiving triple therapy have been exposed to topical drugs for a longer period of time than patients on single drug therapy, duration of drug or preservative exposure may be the factor of most importance. However, the results of their study indicate that impression cytology could be useful in detecting adverse conjunctival changes caused by topical therapy before trabeculectomy. Research relating epithelial changes to the degree of subepithelial changes would be useful to confirm this, since subepithelial pathology is of more significance in relation to bleb failure.
In vitro evidence for an adverse effect of topical antiglaucoma medications

Caution must be exercised in comparing in vitro studies with the in vivo state. Clinically, the instillation of eye drops exposes the conjunctiva to medication for a short period, whereas in tissue culture there is continuous exposure. Furthermore, in vitro experimentation does not allow for natural replacement of damaged tissue during intervals between drug installation. Nevertheless, in order to determine whether cellular changes in the conjunctiva are a direct effect of antiglaucoma medications, tissue culture experimentation enables carefully controlled investigation.

Takahashi $^{33-57}$ studied the effect of antiglaucoma medications and their preservatives on cultured human conjunctival cells. Preservative (benzalkonium chloride) was found to be cytotoxic at concentrations above $0.005 \%$. Pilocarpine ( $1 \%)$ and timolol $(0 \cdot 5 \%)$ alone were not cytotoxic. Adrenaline ( $1 \cdot 25 \%)$ and befnolol ( $0.5 \%)$ alone showed some cytotoxicity after exposure of more than 1 hour, but the $\beta$ blocker, bupranolol $(0.25 \%)$ alone was found to be the most cytotoxic, showing a differential effect of the $\beta$ blockers tested. The cells used in these experiments were conjunctival epithelial cells and the results are thus of only limited value in our understanding of the effect that topical medications have on subepithelial fibroblast proliferation, which is of more importance with respect to failure of filtration surgery.

Williams et $a l,{ }^{58}$ therefore, investigated the effects of the preservative benzalkonium chloride and commercially available $\beta$ blockers (with or without preservative) on cultures of human Tenon's capsule fibroblasts. None of the tested drugs stimulated fibroblast proliferation and, instead, they were found to be irreversibly toxic to fibroblasts at clinically used concentrations. In addition, it was found that pure preparations of the $\beta$ blockers prevented cell attachment at a higher concentration than did the commercially available, preservative-containing versions, and therefore benzalkonium chloride was implicated as a toxic component in terms of cellular attachment. With respect to acute effects on cell proliferation the preservative-free timolol preparation was significantly less toxic than the preservative-containing timolol. Again this finding implicated benzalkonium chloride, which was identified as the most toxic agent tested. However, similar findings to those with timolol were not found with the other $\beta$ blockers (levobunolol or betaxolol). From the study of delayed effects on cell proliferation, using the commercially available preparations, levobunolol was found to be the only drug that became less toxic after the cells were washed free of drug and recultured. Since the benzalkonium chloride concentration in the preservativecontaining levobunolol preparation was $2 \cdot 5$-fold less than in the other $\beta$ blockers, it was proposed that the cells exposed to levobunolol may have been more able to recuperate from the initial injury in comparison with those exposed to the other drugs with more preservative.

The results of this study do not support the hypothesis that antiglaucoma medications directly stimulate fibroblast growth, and thus favour the concept of topical therapy causing tissue irritation, associated low grade chronic inflammation, and indirect fibroblast stimulation. Alternatively, it is possible that the effect of other classes of drug alone (for example, sympathomimetics or miotics) or combination therapy differs from that of $\beta$ blockers and/or preservative, for few studies have looked at the effect of $\beta$ blockers alone on the cellular content of the conjunctiva.

The relationship between conjunctival changes and the outcome of trabeculectomy

The most important issue in relation to trabeculectomy is whether any conjunctival changes are directly related to the 
surgical outcome. A pilot study using an animal model has provided evidence for an adverse effect of topical therapy on fistulised rabbit conjunctiva ${ }^{59}$ but an equivalent analysis in humans is not feasible. In this animal study conjunctival specimens were obtained 5 days following filtration surgery. In comparison with untreated conjunctiva, that pretreated with 4 months of pilocarpine, timolol, or artificial tears had significantly more myofibroblasts. Surprisingly, adrenaline treated conjunctiva showed a non-significant increase and the rise was significantly less than that in conjunctiva exposed to artificial tears. The fact that artificial tears elicited a response suggested that the benzalkonium chloride preservative, present in all the medications used, was responsible and it was suggested that the vasoconstrictive properties of adrenaline may have accounted for its low response. Unfortunately the significance of this study is limited by being a non-primate animal study, the small number of animals included in the study, and that the statistical analysis may have been biased by the fact that both eyes of each animal were analysed. However, in conclusion the authors suggested that prior medical treatment, especially with pilocarpine, may contribute to a lower success rate of filtration surgery by stimulating an exaggerated myofibroblastic response. The actual effect of these cellular changes on the eventual outcome of surgery was not determined although no correlation was established between any type of medication and bleb function or IOP before conjunctival biopsy. In order to determine the effect of medication on surgical outcome the blebs would have to have been observed for a longer duration. Filtration surgery of this type in untreated rabbit eyes has been shown to fail predictably by 2 weeks ${ }^{60}$ and in the light of the study by Young et $a l^{59}$ it would thus be of interest to determine whether pilocarpine treated eyes fail earlier.

\section{Conclusion}

Long term therapy with topical medication induces a degree a conjunctival inflammation and also has an adverse effect on the outcome of filtration surgery. Whether conjunctival changes are the cause rather than merely an association with the poorer surgical results requires further clarification. Sympathomimetics and, to a lesser extent, miotics appear to have a more pronounced adverse effect in comparison with $\beta$ blockers, but preservatives and factors such as duration of therapy undoubtedly play a significant role. Further studies aimed at identification of specific causative factors would be useful.

In spite of our ignorance, there is growing evidence that long term therapy with multiple topical medications is detrimental to both conjunctiva and the success of filtration surgery. In terms of the management of patients with glaucoma such evidence lends support to the strategy of earlier surgical intervention.

DB is supported by the Frost Trust, London, UK.

Moorfields Eye Hospital,

DAVID BROADWAY IAN GRIERSON

City Road, London EC1V 2PD ROGER HITCHINGS

1 Longstaff S, Wormald RPL, Mazover A, Hitchings RA. Glaucoma triple procedures: efficacy of intraocular pressure control and visual outcome. Ophthalmic Surg 1990; 21: 786-93.

2 Lavin MJ, Wormald RPL, Migdal CS, Hitchings RA. The influence of prior therapy on the success of trabeculectomy. Arch Ophthalmol 1990; 108: 1543-8.

3 Miller MH, Rice NSC. Trabeculectomy combined with $\beta$ irradiation for congenital glaucoma. Br $\mathcal{F}$ Ophthalmol 1991; 75: 584-90.

4 Feldman RM, Gross RL, Spaeth GL, Steinmann WC, Varma R, Katz LJ, et al. Risk factors for the development of Tenon's capsule cysts afte trabeculectomy. Ophthalmology 1989; 96: 336-41.

5 Liesegang TJ. Bulbar conjunctival follicles associated with dipivefrin therapy. Ophthalmology 1985; 92: 228-33.
6 Corwin ME, Spencer WH, Conjunctival melanin deposits. Arch Ophthalmol 1963; 69: 317-21.

7 Podos SM. Pharmacology of ocular drugs. 2. Epinephrine. Ophthalmology 1980; 87: 721-3.

8 Theodore FH. Drug sensitivities and irritations of the conjunctiva. $\mathcal{F} A M A$ 1953; 151: 25-30.

9 Wilson FM. Adverse external ocular effects of topical ophthalmic medications Surv Ophthalmol 1979; 24: 57-88.

10 Wilson FM. Adverse external ocular effects of topical ophthalmic therapy: an epidemiologic, laboratory, and clinical study. Trans Am Ophthalmol Soc 1983; 81: 854-965.

11 Kristensen EB, Norn MS. Benign mucous membrane pemphigoid. 1. Secretion of mucus and tears. Acta Ophthalmol 1974; 52: 266-81.

12 Hoffer KJ. Pemphigoid related to epinephrine treatment (letter). Am $\mathcal{f}$ Ophthalmol 1977; 83: 601 .

13 Pouliquen Y, Patey A,' Foster CS, Goichot L, Savoldelli M. Drug-induced cicatricial pemphigoid affecting the conjunctiva: light and electron microscopic features. Ophthalmology 1986; 93: 775-83.

14 Hirst LW, Werblin T, Novak M, Green WR, Pollack I. Drug-induced cicatrizing conjunctivitis simulating ocular pemphigoid. Cornea 1982; 1: 121-8

15 Tseng SCG, Maumenee AE, Stark WJ, Maumenee IH, Jensen AD, Green WR, et al. Topical retinoid treatment for various dry-eye disorders. Ophthalmology 1985; 92: 717-27.

16 Pattern JT, Cavanagh HD, Allansmith MR. Induced ocular pseudopemphigoid. Am f Ophthalmol 1976; 82: 272-6.

17 Leonard JN, Hobday CM, Haffenden GP, Griffiths CEM, Powles AV, Wright $\mathrm{P}$, et al. Immunofluorescent studies in ocular cicatricial pemphigoid. $\mathrm{Br} \mathcal{f}$ Dermatol 1988; 118: 209-17.

18 Fiore PM, Jacobs IH, Goldberg DB. Drug-induced pemphigoid: a spectrum of diseases. Arch Ophthalmol 1987; 105: 1660-3.

19 Tauber J, Melamed S, Foster CS. Glaucoma in patients with ocular cicatricial pemphigoid. Ophthalmology 1989; 96: 33-7.

20 Mondino BJ. Cicatricial pemphigoid and erythema multiforme. Ophthalmology 1990; 97: $939-52$.

21 Novack GD. Ophthalmic beta-blockers since timolol. Surv Ophthalmol 1987; 31: 307-27.

22 Duzman E, Rosen N, Lazar M. Diacetyl-nadolol: 3-month ocular hypotensive effect in glaucomatous eyes. Br f Ophthalmol 1983; 67: 668-73.

23 Ober M, Scharrer A, David R, Biedner B-Z, Novack GD, Lue JC, et al. Longterm ocular hypotensive effect of levobunolol: results of a one year study. $\mathrm{Br}$ fOphthalmol 1985; 69: 593-9.

24 Van Joost TH, Hup JM, Ros FE. Dermatitis as a side-effect of long-term topical treatment with certain beta-blocking agents. Brf Dermatol 1979; 101: 171-6.

25 Fraunfelder FT, Meyer SM. Drug-induced ocular side effects and drug interactions. Philadelphia: Lea \& Febiger, 1982: 395-7.

26 Cvetkovic D, Parunovic A, Kontic DJ. Konjunktivale Veränderungen bei der lokalen langjährigen medikamentösen Therapie des Glaukoms. Fortschr Ophthalmol 1986; 83: 407-9.

27 Wright P. Squamous metaplasia or epidermalization of the conjunctiva as an adverse reaction to topical medication. Trans Ophthalmol Soc UK 1979; 99: $244-6$.

28 Derous D, de Keizer RJW, de Wolff-Rouendaal D, Soudijn W. Conjunctival keratinisation, an abnormal reaction to an ocular beta-blocker. Acta Ophthalmol 1989; 67: 333-8.

29 Wright P. Untoward effects associated with practolol administration: oculomucocutaneous syndrome. BMJ 1975; 1: 595-8.

30 Rahi AHS, Chapman CM, Garner A, Wright P. Pathology of practolol-induced ocular toxicity. Brf Ophthalmol 1976; 60: 312-23.

31 Wright P. Cicatrizing conjunctivitis. Trans Ophthalmol Soc UK 1986; 105: 1-17.

32 Schwab IR, Linberg JV, Gioia VM, Benson WH, Chao GM. Foreshortening of the inferior conjunctival fornix associated with chronic glaucoma medications. Ophthalmology 1992; 99: 197-202.

33 Sherwood MB, Grierson I, Millar L, Hitchings RA. Long-term morphologic effects of antiglaucoma drugs on the conjunctiva and Tenon's capsule in glaucomatous patients. Ophthalmology 1989; 96: 327-35.

34 Smith DL, Skuta GL, Kincaid MC, Rabbani R, Cruess DF, Kao SF. The effects of glaucoma medications on Tenon's capsule and conjunctiva in the effects of glaucoma medications on Tenon'

35 Broadway DC, Grierson I, O'Brien C, Hitchings RA. The effect of topical antiglaucoma medication on the conjunctival cell profile and the results of the trabeculectomy. Invest Ophthalmol Vis Sci 1993; 34: 724.

36 Varga M, Follman P. Feinstrukurelle Untersuchungen der Bindehautoberfläche nach Langzeitbehandlung mit Timolol. Fortschr Ophthalmol 1986; 83: 155-7.

37 Van Buskirk EM. Adverse reactions from timolol administration. Ophthalmology 1980; 87: 447-50.

38 Van Buskirk EM. Corneal anaesthesia after timolol maleate therapy. Am $\mathcal{F}$ Ophthalmol 1979; 88: 739-43.

39 Strempel I. The influence of topical $\beta$-blockers on the break-up time. Ophthalmologica 1984; 189: 110-15.

40 Strempel I. Immediatwirkung topischer $\beta$-blocker auf der "breakup time". Ophthalmologica 1986; 192: 11-6.

41 Bonomi L, Zavarise G, Noya E, Michiletto S. Effects of timolol maleate on tear flow in human eyes. Graefes Arch Clin Exp Ophthalmol 1980; 213: 19-22.

42 Levobunolol Study Group. Levobunolol: a beta-adrenoceptor antagonist effective in the long-term treatment of glaucoma. Ophthalmology 1985; 92: 1271-6.

43 Coakes RL, Mackie IA, Seal DV. Effects of long-term treatment with timolol on lacrimal gland function. $\mathrm{Br} \mathcal{F}$ Ophthalmol 1981; 65: 603-5.

44 Neilsen NV, Eriksen JS. Timolol and metoprolol - glaucoma: a comparison of the ocular hypotensive effect, local and systemic tolerance. Acta Ophthalmol 1981; 59: 336-46.

45 Herreras JM, Pastor JC, Calonge M, Asensio VM. Ocular surface alteration after long-term treatment with an antiglaucomatous drug. Ophthalmology 2; 99: 1082-8.

46 Steuhl KP, Knorr M, Frohn A, Thiel H-J. Über den Einfluß antiglaukomatöser Augentropfen auf die Zelldifferenzierung der Konjunktiva. Fortschr Ophthalmol 1991; 88: 865-9.

47 Quaranta CA, Russo L, Rossi Brunori P, Vigasio F, Ballini S, Grigolato PG, et al. Osservazioni ultrastruttturali sugli ipotetici danni congiuntivali da farmaci beta-bloccanti. Bollettino di Oculistica 1988; 67 (suppl 3): 345-51. 
48 Hoffman JP. Timoptic product information summary. West Point, PA: Merck, Sharp and Dohme, 1978: 7.

49 Gerstenberger A, Marquardt R. Die Becherzelldichte unter Pilocarpineinfluss. Fortschr Ophthalmol 1986; 83: 46-50.

50 Ruskell GL. Innervation of the conjunctiva. Trans Ophthalmol Soc UK 1985; 104: $390-5$

51 Kirchner C. Untersuchungen über das Ausmass der Tränensekretion beim Menschen. Klin Monatsbl Augenheilkd 1964; 144: 412-7.

52 Brandt JD, Wittpenn JR, Katz LJ, Steinmann WN, Spaeth GL. Conjunctival impression cytology in patients with glaucoma using long-term topica medication. Am F Ophthalmol 1991; 112: 297-301.

53 Takahaski $\mathrm{N}$. Cytotoxicity of preservatives on cultured human conjunctival cells. Acta Soc Ophthalmol fpn 1980; 84: 1171-6.

54 Takahashi N. Cytotoxic effects of antiglaucoma agents on cultured human conjunctival cells. Acta Soc Ophthalmol fpn 1981; 85: 1046-52.
55 Takahashi N. Cytotoxicity of mercurial preservatives in cell culture. Ophthalmic Res 1982; 14: 63-9.

56 Takahashi N. Quantitative cytotoxicity of preservatives evaluated in cell culture with Chang's human conjunctival cells - effect of temperature on culture with Chang's human conjunctival cells - effect of temperature on

57 Takahashi N. A new method evaluating quantitative time-dependent cytotoxicity of ophthalmic solutions in cell culture. Beta-adrenergic blocking agents. Graefes Arch Clin Exp Ophthalmol 1983; 220: 264-7.

58 Williams DE, Nguyen KD, Shapourifar-Tehrani S, Kitada S, Lee DA. Effects of timolol, betaxolol, and levobunolol on human Tenon's fibroblasts in tissue culture. Invest Ophthalmol Vis Sci 1992; 33: 2233-41.

59 Young TL, Higginbotham EJ, Zou X, Farber MD. Effects of topical glaucoma drugs on fistulized rabbit conjunctiva. Ophthalmology 1990; 97: 1423-7.

60 Seetner A, Morin JD. Healing of trabeculectomies in rabbits. Can f Ophthalmol 1979; 14: 121-5. 